\title{
Velocity increases at Cook Glacier, East Antarctica, linked to ice shelf loss and a subglacial flood event
}

\author{
Bertie W. J. Miles, Chris R. Stokes, and Stewart S. R. Jamieson \\ Department of Geography, Durham University, Science Site, South Road, Durham, DH1 3LE, UK
}

Correspondence: Bertie W. J. Miles (a.w.j.miles@durham.ac.uk)

Received: 17 May 2018 - Discussion started: 1 June 2018

Revised: 21 August 2018 - Accepted: 5 September 2018 - Published: 2 October 2018

\begin{abstract}
Cook Glacier drains a large proportion of the Wilkes Subglacial Basin in East Antarctica, a region thought to be vulnerable to marine ice sheet instability and with potential to make a significant contribution to sea level. Despite its importance, there have been very few observations of its longer-term behaviour (e.g. of velocity or changes at its ice front). Here we use a variety of satellite imagery to produce a time series of ice front position change from 1947 to 2017 and ice velocity from 1973 to 2017. Cook Glacier has two distinct outlets (termed East and West), and we observe the near-complete loss of the Cook West Ice Shelf at some time between 1973 and 1989. This was associated with a doubling of the velocity of Cook West Glacier, which may also be linked to previously published reports of inland thinning. The loss of the Cook West Ice Shelf is surprising given that the present-day ocean climate conditions in the region are not typically associated with catastrophic ice shelf loss. However, we speculate that a more intense ocean climate forcing in the mid-20th century may have been important in forcing its collapse. Since the loss of the Cook West Ice Shelf, the presence of landfast sea ice and mélange in the newly formed embayment appears to be important in stabilizing the glacier front and enabling periodic advances. We also show that the last calving event at the larger Cook East Ice Shelf resulted in the retreat of its ice front into a dynamically important portion of the ice shelf and observe a short-lived increase in velocity of Cook East between 2006 and 2007, which we link to the drainage of subglacial Lake Cook. Taken together, these observations suggest that the velocity, and hence discharge, of Cook Glacier is highly sensitive to changes at its terminus, but a more detailed process-based analysis of this potentially vulnerable region requires further oceanic and bathymetric data.
\end{abstract}

\section{Introduction}

Ice which is grounded well below sea level in the marine basins of Antarctica with an inland-sloping bed is potentially vulnerable to marine ice sheet instability. This is because an initial grounding line retreat into deeper water can create an unstable and self-sustaining feedback leading to increased ice discharge, inland thinning, and a rapid sea level contribution (Hughes, 1981; Schoof, 2007). Floating ice shelves are crucial to the stability of ice streams and outlet glaciers that drain marine basins because they can exert an important buttressing effect (Furst et al., 2016). Thinning or retreat of these ice shelves reduces their ability to restrain flow from the ice sheet (Pritchard et al., 2012). This is evident in parts of the West Antarctic Ice Sheet (WAIS) where the feedbacks resulting from the rapid thinning of ice shelves (Paolo et al., 2015) has resulted in an increased discharge of ice into the ocean (Mouginot et al., 2014). This oceanic-driven thinning of ice shelves may have destabilized the Thwaites Glacier basin, where marine ice sheet instability may already be underway, and which might undermine much of the WAIS over the coming decades to centuries (Joughin et al., 2014).

The Wilkes Subglacial Basin (WSB) in East Antarctica contains 3-4 m sea level equivalent of ice grounded below sea level (Mengel and Levermann, 2014). Geological evidence suggests the WSB may have made substantial $(\sim 3 \mathrm{~m})$ sea level contributions during the warm interglacials of the Pliocene (Williams et al., 2010; Cook et al., 2013; Bertram et al., 2018), which are thought to represent the best analogue for near-future climates under continued global warming. Indeed, numerical ice sheet models predict future sea level contributions from the WSB, but the magnitude and timing of the contributions vary (Golledge et al., 2015; Ritz et al., 2015; DeConto and Pollard, 2016). Furthermore, dynamical mod- 
elling of the present-day ice sheet margin of the WSB shows that its stability might be controlled by a relatively small band of coastal ice ( $\sim 80 \mathrm{~mm}$ sea level equivalent), which is preventing a self-sustained discharge of the entire basin (Mengel and Levermann, 2014). The majority of this coastal band of ice is drained by Cook Glacier (Mengel and Levermann, 2014), which is one of the largest in Antarctica. Its current configuration consists of two distinct distributaries: Cook East and Cook West (Fig. 1). Cook East flows into a large $80 \mathrm{~km}$ long ice shelf, whereas Cook West terminates close to, or at, its grounding line (Fig. 1). Despite having one of the largest annual discharges of any Antarctic outlet glacier (Rignot et al., 2013) $\left(\sim 36 \mathrm{Gt} \mathrm{a}^{-1}\right)$, and given its potential significance to the stability of the WSB, there have been very few observations of its recent behaviour. Along with Totten Glacier, it was specifically highlighted in the most recent IPCC report (Vaughan et al., 2013) as being potentially vulnerable to marine ice sheet instability, but, unlike Totten, there has been no obvious changes in ice shelf thickness, ice surface elevation, or grounding line position over the past decade (Pritchard et al., 2009; McMillan et al., 2014; Paolo et al., 2015; Konrad et al., 2018). However, some studies have previously highlighted Cook as a region of modest inland thinning (e.g. Shepherd and Wingham, 2007), and Frezzotti et al. (1998) reported a major retreat of the Cook West Glacier, which others have suggested might be flowing too fast to be in balance (Rignot, 2006). In this paper, we report on the long-term changes in Cook Glacier by combining measurements of ice front position from 1947 to 2017, together with glacier velocity estimates from 1973 to 2017 from optically based feature tracking. Our results indicate that, despite little change over the past decade, there has been a long-term increase in the velocity of both Cook East and Cook West glaciers that can be linked to changes at its ice front.

\section{Methods}

\subsection{Ice front position change}

We revisit and extend the results of Frezzotti et al. (1998) by using a combination of oblique aerial photography from "Operation Highjump" in 1947 and ARGON, RADARSAT, ASTER, Landsat, and WorldView-2 satellite imagery to create a 70-year time series of ice front position change from 1947 to 2017 for both Cook West and Cook East glaciers (Table S1 in the Supplement). Changes in ice front position were quantified by the well-established box method, which takes into account uneven changes along the ice front (e.g. Moon and Joughin, 2008). Errors using this method arise from the co-registration of satellite images, quantified by digitizing the distance between stable features on image pairs (1 pixel) and the manual digitization of the ice front, which has been calculated at 0.5 pixels in other studies (e.g. Miles et

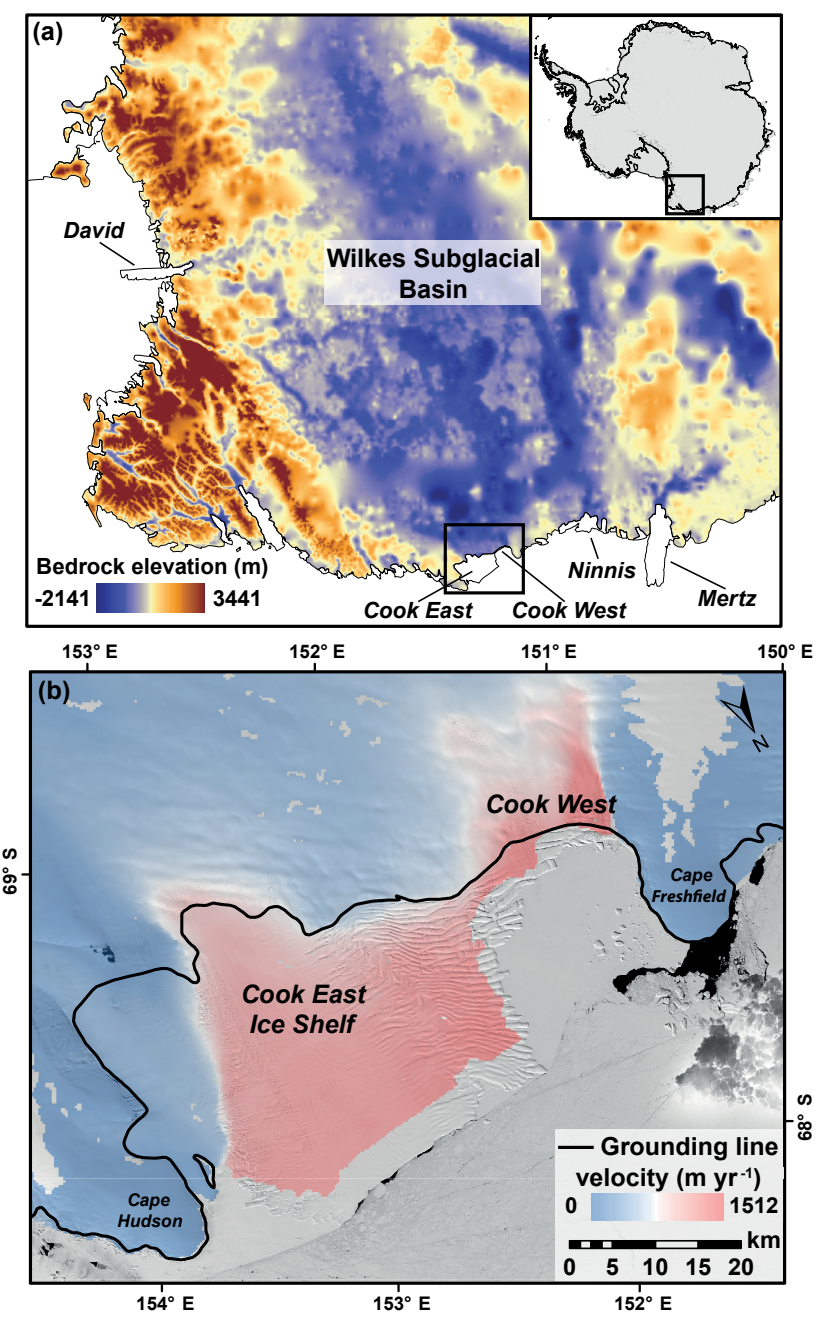

Figure 1. (a) Bedmap2 bed elevation of the Wilkes Subglacial Basin (Fretwell et al., 2013); note that Cook East and West drain a large proportion of the Wilkes Subglacial Basin. (b) Landsat-8 image of Cook East and West glaciers from February 2017, overlain with velocities (Rignot et al., 2011) and grounding line (Depoorter et al., 2013).

al., 2013, 2016), giving an estimated total error of 1.5 pixels $(22.5-90 \mathrm{~m})$. These errors are in the range of similar studies and are insignificant when quantifying ice front position change of large Antarctic outlet glaciers (Miles et al., 2013, 2016). Because the 1947 aerial photographs were taken at an oblique angle, we estimate the ice front position relative to stable features which have not moved over time (e.g. ice rises). This creates larger uncertainties compared with measurements from orthorectified satellite imagery. We estimate these uncertainties at $\sim \pm 2 \mathrm{~km}$.

\subsection{Glacier velocity from feature tracking}

Estimates of glacier velocity were derived using COSI-Corr (Co-registration of Optically Sensed Images and Correlation) 
feature-tracking software (Leprince et al., 2007; Scherler et al., 2008). This software tracks spectral signatures which relate to features on the glacier surface that can be identified in multiple images through time, and it has been shown to be one of the most robust methods of glacier velocity mapping (Heid and Kääb, 2012). It requires pairs of co-registered optical cloud-free images which are spaced close enough in time for surface features to be identified in both images. In this study, the temporal resolution of image pairs was largely determined by the availability of appropriate satellite imagery, which was generally sparse due to a combination of poor coverage and persistent cloud cover. However, by using a combination of Landsat-1, Landsat-4, Landsat-7, ASTER, and Landsat-8, we were able to create a velocity time series from 1989 to 2016 for Cook East (Table S2) and from 1973 to 2017 for Cook West (Table S3). Image pairs were typically spaced 1 year \pm 100 days apart, which is a suitable gap for the preservation of surface features. The exception to this was in 1973-1974, where image availability only allowed temporal gap of 73 days (Table S3).

The COSI-Corr procedure first requires the accurate coregistration of image pairs. For Landsat- 8 image pairs the orbital data were of sufficient quality (e.g. Mouginot et al., 2017) that no further manual co-registration was required. However, for all other image pairs, manual co-registration was required and was achieved by using a combination of nunataks and the boundaries of ice rises, which are known to be stable features over time. Because these features are relatively common in the vicinity of Cook Glacier, image pairs could be co-registered to an estimated accuracy of 1 pixel. We used a window size of $256 \times 256$ pixels and a grid size of $20 \times 20$ pixels to detect surface displacement, which results in the production of velocity fields at a resolution 20 times coarser than the pixel resolution of the image pair (Tables S2 and S3). Error in surface displacement was estimated at 0.5 pixels by manually tracking large surface features, which is consistent with other studies using this method (Scherler et al., 2008; Heid and Kääb, 2012). Total error ranged from $\pm 51 \mathrm{~m} \mathrm{yr}^{-1}$ in 1989 to between \pm 19 and $\pm 24 \mathrm{~m} \mathrm{yr}^{-1}$ from 2000 to 2017 (Tables S2 and S3). The coarser resolution and closer temporal resolution of the 1973-1974 Landsat-1 image pairs resulted in a considerably higher error of $\pm 450 \mathrm{~m} \mathrm{yr}^{-1}$ (Table S3).

Post-processing of ice velocity grids can reduce noise and remove erroneous pixels (e.g. Mouginot et al., 2017). We removed pixels where the velocity was greater than $\pm 25 \%$ of the MEASURES ice velocity product in velocity grids from 2000 to 2017 and $\pm 40 \%$ in the velocity grid from 1989 to account for any larger changes in glacier velocity. For the 1973-1974 velocity grid, we filtered out all pixel values below $450 \mathrm{~m} \mathrm{yr}^{-1}$ to account for the larger error of the Landsat1 image pair. We then applied a low-pass filter to all velocity grids to create the final products (Fig. S1 in the Supplement). To create the velocity time series, we extracted the mean value of pixels within a defined box across all epochs, and in each epoch all pixels were sampled within the defined box; i.e. there were no rejected pixels. For Cook East the defined box was on a section across the grounding line (Fig. S1). As Cook West terminates close to its grounding line, we extracted velocities $2 \mathrm{~km}$ upstream (Fig. S1).

\subsection{Ice front advance rate}

Preliminary inspection of the imagery clearly indicated that there have been no major calving events on the Cook East Glacier since 1973 because the shape of the ice margin is unchanged. Thus, we were able to create a time series of the rate of ice front advance between 1973 and 2016. Although it is not a direct measurement of glacier velocity, the rate of ice front advance is helpful in enabling additional independent estimates of ice advance (a proxy for ice velocity at the terminus if no major calving events have taken place) further back in time (i.e. between 1973 and 1989) and allows additional measurements to be made in the 1990s (Table S4). Ice front advance rate was quantified by dividing ice front position change by the number of days between image pairs. Taking into account the error of 1.5 pixels associated with co-registration and manual mapping, errors were estimated between \pm 1 and $\pm 86 \mathrm{~m} \mathrm{yr}^{-1}$, with range in error accounting for the varying spatial resolution of images and the temporal gap between image pairs (Table S4).

\section{Results}

\subsection{Cook East}

The Cook East Ice Shelf last underwent a major calving event at some point between 1963 and 1973 (Figs. 2 and 3). This calving event resulted in the retreat of its ice front deep into the constrained section of its embayment, resulting in the loss of all passive ice and retreat into the dynamically constrained section of the ice shelf (Furst et al., 2016) (Fig. 2). Since 1973 it has advanced $\sim 31 \mathrm{~km}$ and there have been no major calving events. By extrapolating the rate of advance between 1947 and 1963 to establish Cook East's maximum possible extent, it is clear that its present-day ice front is further advanced (by $\sim 6 \mathrm{~km}$ ) than the point at which it last underwent a major calving event/retreat.

The velocity of Cook East increased approximately $20 \%$ from $416 \pm 51 \mathrm{~m} \mathrm{yr}^{-1}$ in 1989 to $496 \pm 19 \mathrm{~m} \mathrm{yr}^{-1}$ in 2000 2001 (Fig. 3b). Throughout 2001 to 2016 velocity remained consistent with an average speed of $489 \mathrm{~m} \mathrm{yr}^{-1}$, with little year-to-year deviation. The only exception to this was between 2006 and 2007, where Cook East was flowing 12\% $\left(545 \pm 22 \mathrm{~m} \mathrm{yr}^{-1}\right)$ faster than its 2001-2016 average. Velocity profiles across the Cook East Ice Shelf show similar patterns (Fig. 4); with the exception of 1989 and 2006-2007, all profiles are clustered in a narrow band. In 1989 velocity was anomalously slow across the entire ice shelf, and between 2006 and 2007 velocity was anomalously fast. No- 


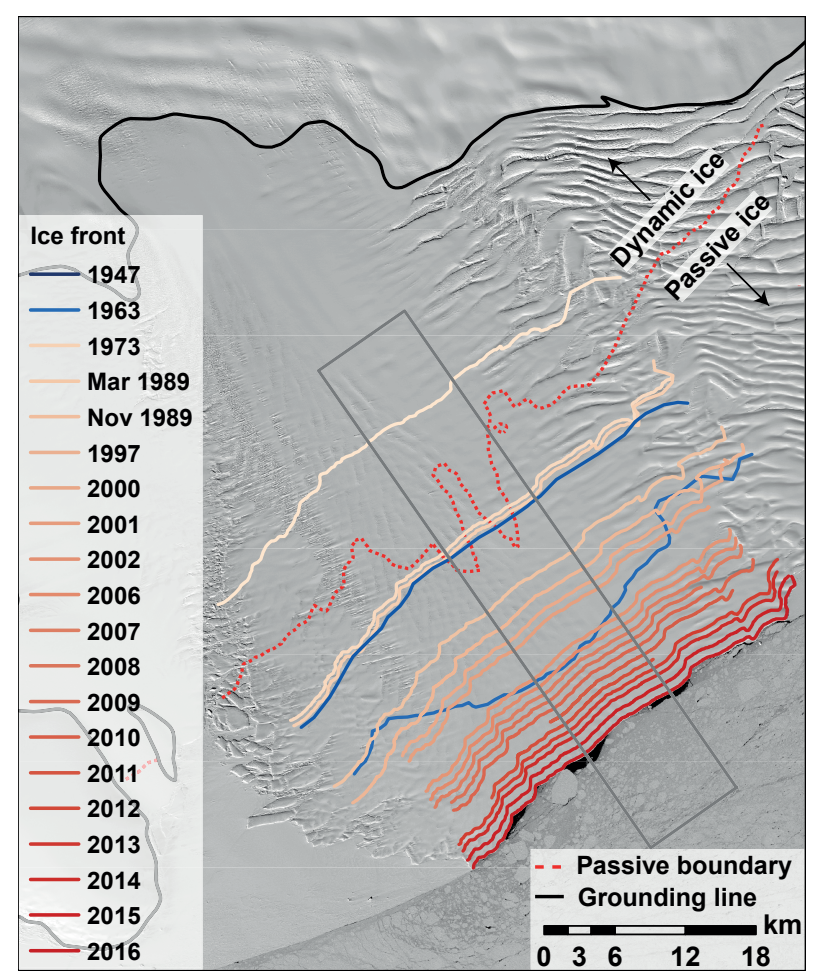

Figure 2. Mapped ice front position of the Cook East Ice Shelf between 1947 and 2016, with the passive ice boundary overlain (Furst et al., 2016). Note that the 1973 ice front position of Cook East lies several kilometres inland of the passive ice boundary. The grey box delineates the region where ice front position change was calculated.

tably, these patterns also persist several kilometres upstream of the grounding line (Fig. 4).

There was little change in the rate of mean ice front advance between 1973 and 1997. However, from 1997 to 2000 $\left(720 \pm 20 \mathrm{~m} \mathrm{yr}^{-1}\right)$ and from 2002 to $2006\left(749 \pm 8 \mathrm{~m} \mathrm{yr}^{-1}\right)$ there was a consistent increase in the rate of ice front advance (Fig. 3c). This is consistent with velocity estimates from the grounding line which show an increase in velocity between 1989 and 2001. Throughout 2002-2016 there were small internannual variations in ice front advance rate, with no obvious trend. In a similar manner to velocity estimates from the grounding line, the only exception to this was between 2006 and 2007, where the ice front advanced at $792 \pm 30 \mathrm{~m} \mathrm{yr}^{-1}$, higher than the 2002-2016 average (752 $\mathrm{m} \mathrm{yr}^{-1}$ ) (Fig. 3c).

\subsection{Cook West}

From 1947 to 2018 the Cook West ice front retreated approximately $34 \mathrm{~km}$ (Figs. 5 and 6). This retreat largely occurred in two stages, with retreat initiating between 1947 and 1963, when Cook West retreated $20 \mathrm{~km}$, before stabilizing between 1963 and 1973, when the ice front retreated $2.8 \mathrm{~km}$ and there was no obvious change in the surface structure of the ice shelf (Fig. 5). From 1973 to 1989 the remaining section of
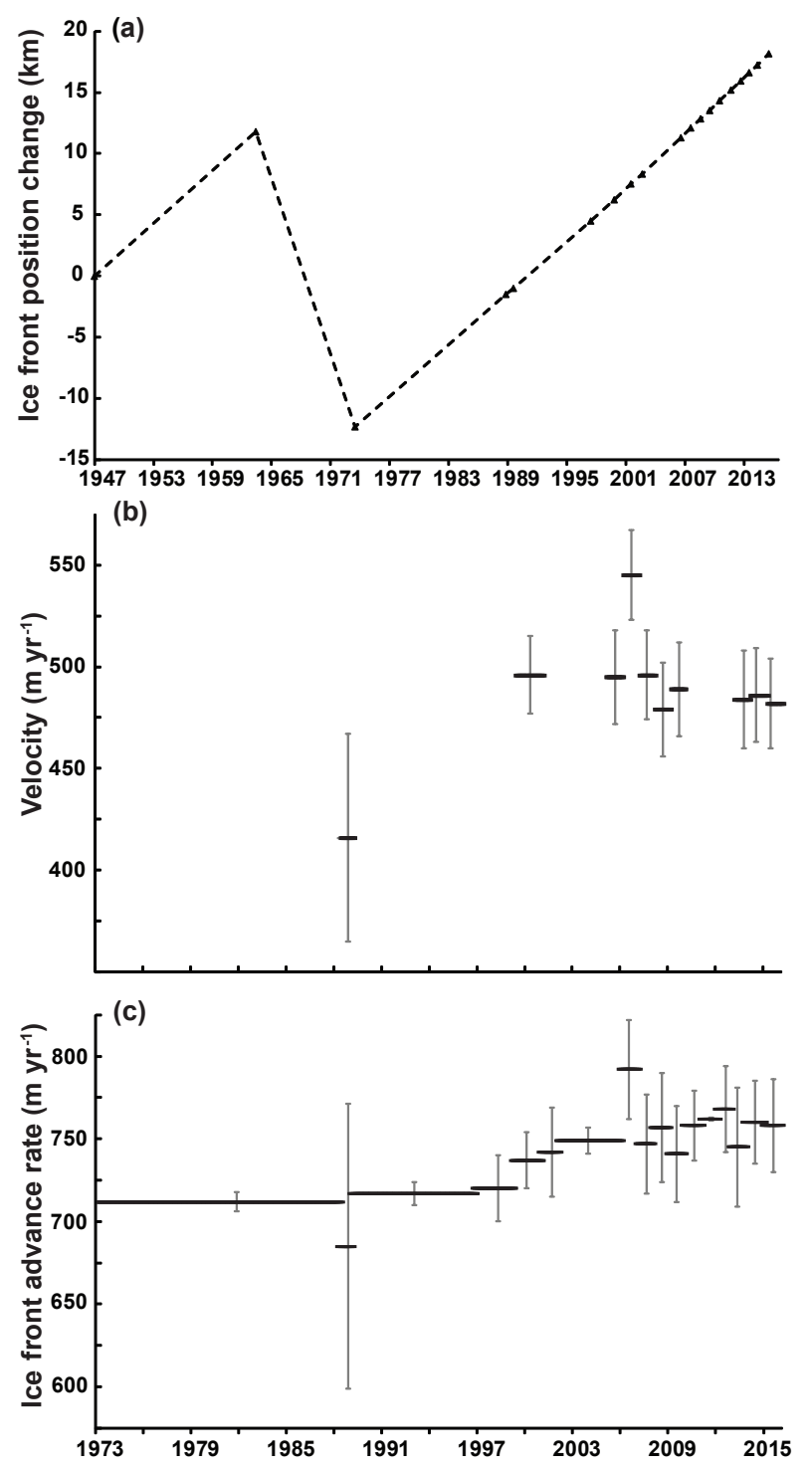

Figure 3. (a) Ice front position change of the Cook East Ice Shelf during 1947-2016 from the grey box delineated in Fig. 2. (b) Mean velocity extracted at the grounding line of Cook East during 19892016. (c) Cook East ice front advance rate during 1973-2016. Note the increase in both velocity (b) and ice front advance rate (c) in the 1990s and between 2006 and 2007. Grey bars represent the errors in both (b) and (c).

the Cook West Ice Shelf retreated $13 \mathrm{~km}$ close to, or onto, its present grounding line (Figs. 5 and 6). This resulted in the estimated total loss of $1200 \mathrm{~km}^{2}$ of ice shelf between 1947 and 1989. The large retreat of $5 \mathrm{~km}$ between November 1973 and January 1974 (Figs. 5 and 6) suggests that this retreat was more likely to have occurred in the mid-1970s. Since 1989, observations show relatively little change, with only minor fluctuations $(\sim 3 \mathrm{~km})$ in ice front position. Perhaps surprisingly, we observe no signs of a re-advance of Cook West Glacier comparable to its pre-1989 ice front position. 


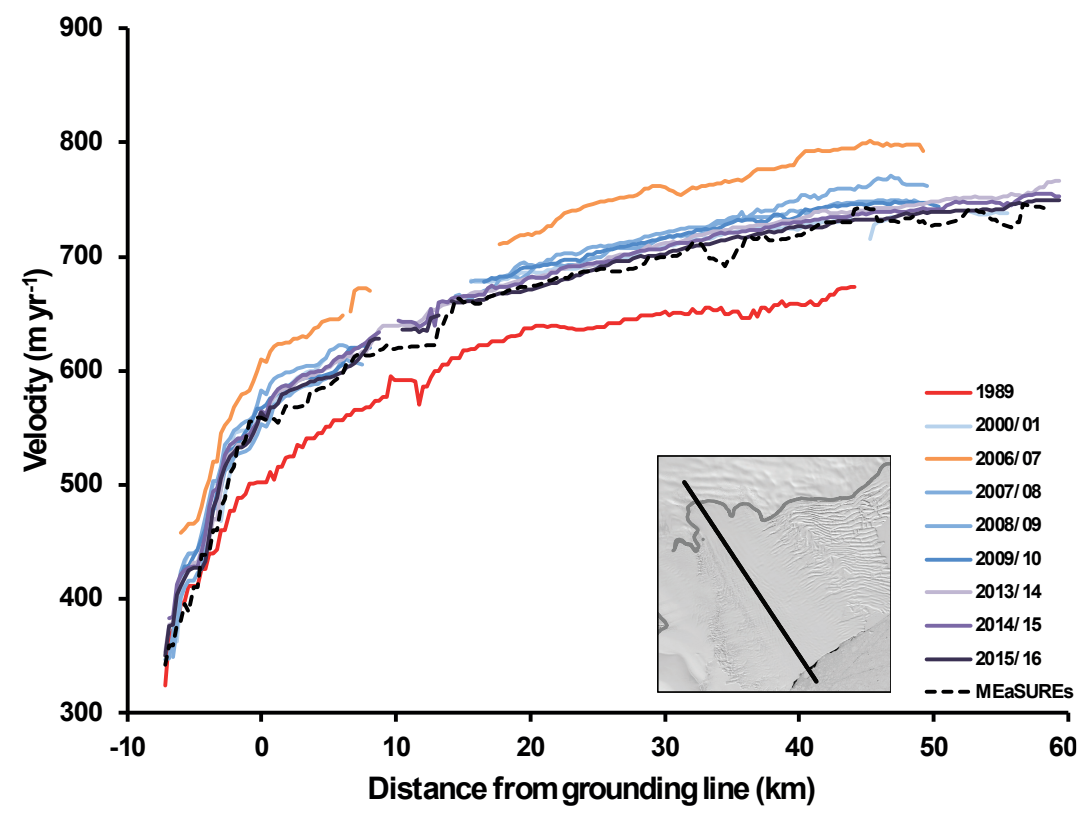

Figure 4. Cross-profile of the velocity of the Cook East Ice Shelf. Velocities were extracted along the same series of points shown in the inset. The dotted line represents velocities extracted from the same cross-profile of the MEaSUREs dataset.
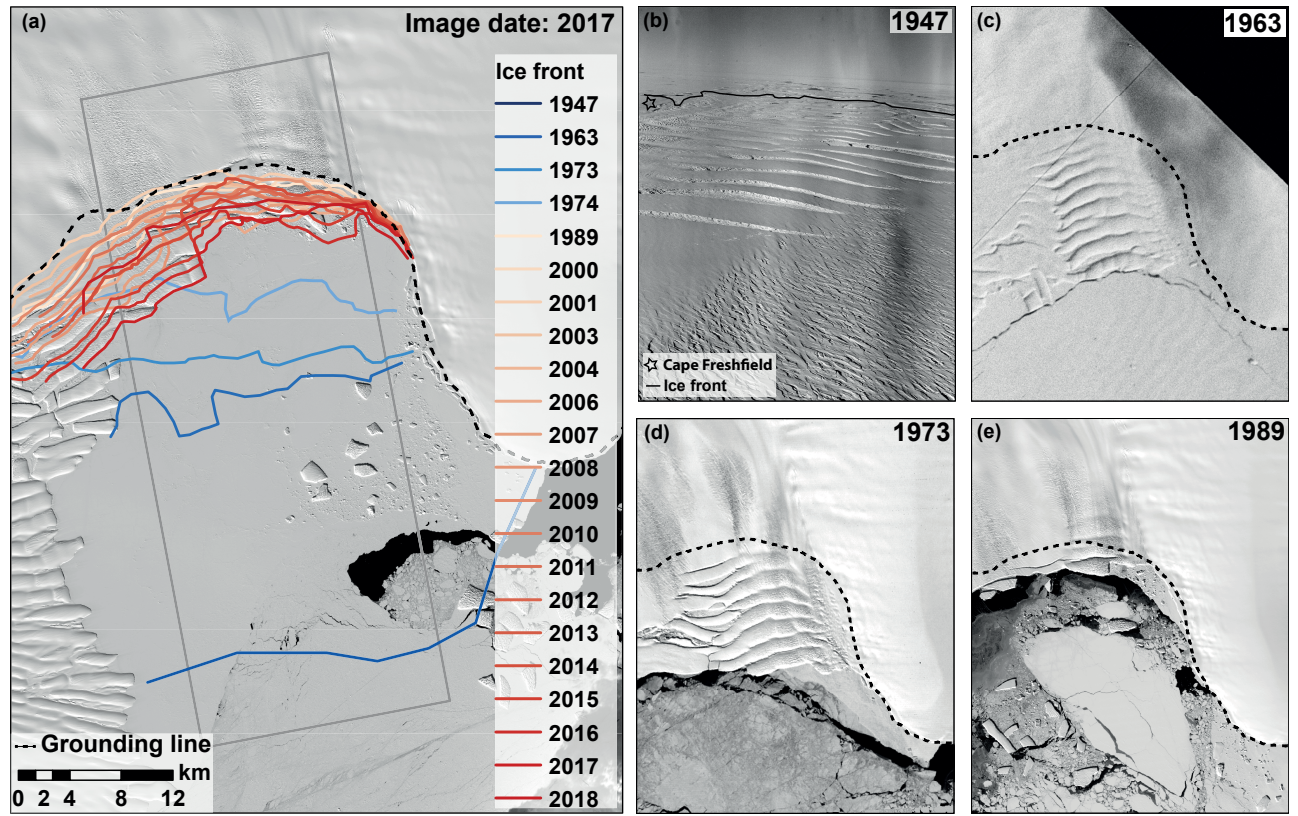

Figure 5. (a) Mapped ice front position of Cook West between 1947 and 2018. Note the exceptional retreat between 1947 and 1989. Grey box delineates the region where ice front position change was calculated. Grounding line is from Depoorter et al. (2013). (b-e) Images of Cook West Glacier in (b) 1947, (c) 1963, (d) 1973, and (e) 1989.

The velocity of Cook West Glacier increased from $692 \pm$ $450 \mathrm{~m} \mathrm{yr}^{-1}$ in $1973-1974$ to $1438 \pm 51 \mathrm{~m} \mathrm{yr}^{-1}$ in 1989 (Fig. 6b). Although the error associated with the 1973-1974 measurement is high, the pair of measurements still demonstrates a major increase in velocity, which coincides with the retreat of the Cook West ice front (Fig. 6b). There were small variations in the velocity of Cook West between 2001 and 2017 , with no velocity estimates deviating from $\pm 5 \%$ of the 2001-2017 mean (1368 $\mathrm{m} \mathrm{yr}^{-1}$ ). Between 2001 and 2017, Cook West was flowing fastest from 2001 to 2002 at $1463 \pm$ $24 \mathrm{~m} \mathrm{yr}^{-1}$ and slowest from 2016 to 2017 at $1306 \pm 22 \mathrm{~m} \mathrm{yr}^{-1}$ (Fig. 6b). 


\section{Discussion}

\subsection{Cook East}

\subsubsection{Long-term behaviour of the Cook East Ice Shelf}

The calving of the Cook East Ice Shelf between 1963 and 1973 resulted in the loss of dynamically important ice (Furst et al., 2016) (Fig. 2). The retreat of large Antarctic ice shelves into the dynamically important sections of their embayment is unusual (Fig. 2); calving events typically occur within the bounds of the unconstrained section of ice shelves (Miles et al., 2013). However, since the retreat between 1963 and 1973, the Cook East Ice Shelf has re-advanced and has remained stable, which is reinforced by data suggesting that there has been little change in the grounding line position of Cook East in recent years (Konrad et al., 2018). This indicates that a terminus retreat deep into an ice shelf embayment does not necessarily result in an irreversible retreat. This observation could be an important consideration in improving our understanding of how recent and future large calving events influence ice shelf stability in Antarctica, e.g. Larsen C (Jansen et al., 2015). The return period of any potential calving cycle at Cook East may be too long to determine if this relatively deep retreat into the embayment is typical of its normal behaviour (Figs. 2 and 3). Based on the morphology and size of an iceberg located near the Mertz Glacier Tongue in satellite imagery in 1984, Frezzotti et al. (1998) estimated that the calving of Cook East between 1963 and 1973 occurred in the early 1970s. This means that its current ice front position is further advanced than its last calving event (Fig. 3a). However, an inspection of the current morphology of the Cook East Ice Shelf reveals no obvious signs of an imminent calving event, and we suggest another calving event is at least several years away.

The increase in velocity between 1989 and 2000-2001 $\left(416 \pm 51\right.$ to $\left.496 \pm 19 \mathrm{~m} \mathrm{yr}^{-1}\right)$ coincided with an increase in the ice front advance rate, and, notably, most of this acceleration is concentrated between 1997 and 2002 (Fig. 3c). On the basis of this, we suggest that the increase in velocity between observations in 1989 and 2000-2001 is likely to have occurred in the late 1990s. There are limited oceanic data available to investigate possible changes in oceanic conditions, but a potential mechanism could be changes in ice shelf thickness driven by enhanced basal melting. Indeed this increase coincides with the intense 1997-1998 El Niño event, which has been linked to abrupt changes in environmental conditions in the Pacific sector of Antarctica and ice shelf mass loss (Paolo et al., 2018).
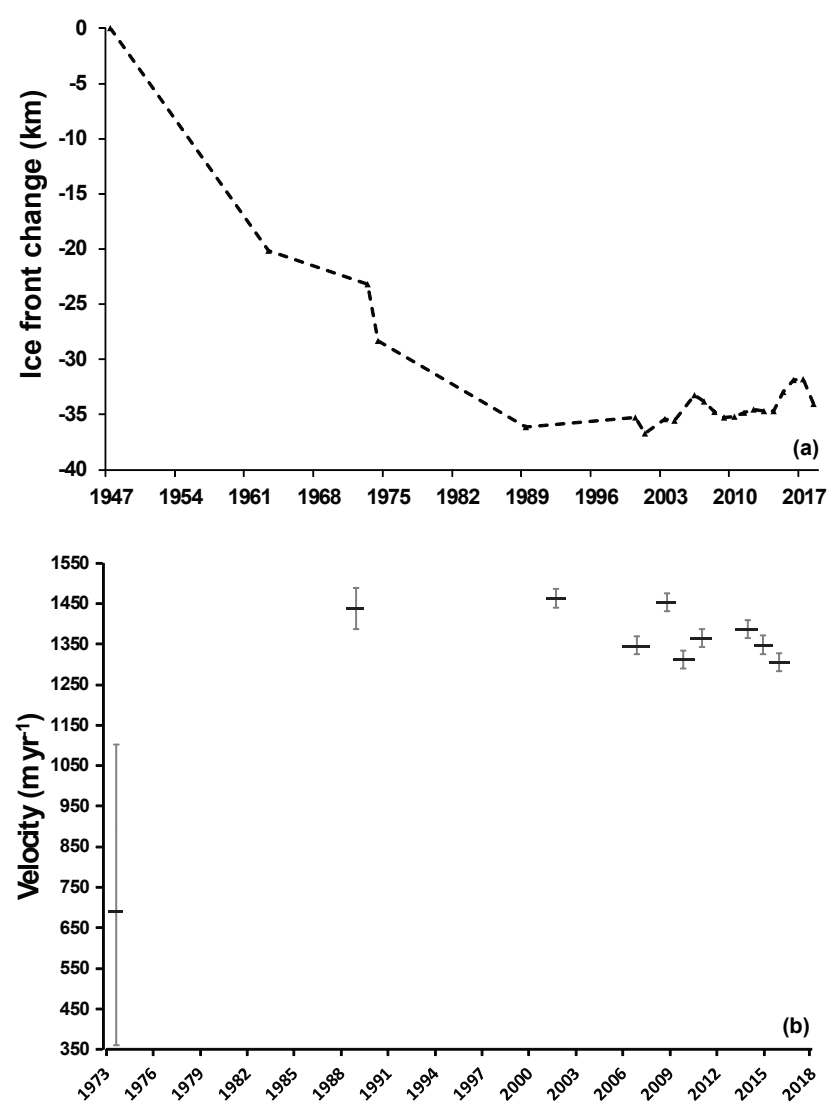

Figure 6. (a) Ice front position time series of Cook West between 1947 and 2018. (b) Velocity estimates and ice front retreat of Cook West Glacier between 1973 and 2017 based on feature tracking. The grey bars represent error. Note the increase in velocity between 1973-1974 and 1989 coincides with the retreat of the Cook West Ice Shelf.

\subsubsection{Drainage of subglacial Lake Cook and short-lived velocity increase}

Between 1 December 2006 and 4 December 2007, the Cook East Ice Shelf was flowing $12 \%$ faster than its 2001-2016 average speed (Fig. 3b). A similar speed-up is also evident on the grounded ice upstream and across the entire ice shelf (Fig. 4). This is a greater magnitude of change than expected by interannual variability. In Antarctica, a small number of short-lived accelerations in glacier flow have been observed and linked to subglacial flood events perturbing basal conditions and leading to enhanced lubrication (e.g. Stearns et al., 2008; Scambos et al., 2011; Siegfried et al., 2016). Between November 2006 and March 2008, we note that a subglacial lake drained $\sim 450 \mathrm{~km}$ upstream of Cook East Glacier (Smith et al., 2009; McMillan et al., 2013; Flament et al., 2014), resulting in the discharge of $5.2 \pm 1.5 \mathrm{~km}^{3}$ (Flament et al., 2014) or between 4.9 and $6.4 \mathrm{~km}^{3}$ (McMillan et al., 2013) of water, the largest single subglacial drainage event ever recorded. The calculated flow path suggests that 
the flood could have reached Cook East, but not Cook West (Flament et al., 2014; Willis et al., 2016) (Fig. 7). Because the timing of these two events coincides, we suggest that the acceleration of Cook East Glacier could have been triggered by the drainage of subglacial Lake Cook. The quick response time between the onset of the drainage event and the increase in velocity suggests that at least some of the flood water flowed rapidly through existing channels, even if some of the floodwater was stored in connecting subglacial lakes (Flament et al., 2014). This adds to the few observations which link changes in subglacial hydrology to glacier flow dynamics in Antarctica (e.g. Stearns et al., 2008; Scambos et al., 2011; Siegfried et al., 2016). This is important because there are a number of other subglacial lakes which could be routed through Cook East Glacier (Wright et al., 2008). If any changes in subglacial hydraulic conditions occur in the future, the sensitivity of Cook East to perturbations in its basal conditions could be an important consideration.

\subsection{Cook West}

\subsubsection{Link between ice shelf retreat and increased velocity}

The near-complete loss of the Cook West Ice Shelf (Figs. 5 and 6) is highly unusual in the context of East Antarctic outlet glaciers in the past 50 years. Broad trends in their ice front position have been linked to climate at decadal timescales, but no other East Antarctic ice shelves have been observed to retreat to their grounding lines and then not re-advanced (Miles et al., 2013, 2016; Lovell et al., 2017). Our results show that the near-complete loss of the Cook West Ice Shelf between 1973 and 1989 coincided with a likely doubling of Cook West's velocity (Fig. 6). This suggests that the increase in velocity was linked to a reduction in buttressing caused by the loss of the Cook West Ice Shelf. It would be expected that an increase in velocity of such magnitude would be accompanied by dynamic inland thinning. Consistent with this notion are satellite altimetry records that, despite covering different time periods between 1992 and 2010, all report an inland thinning signal upstream of Cook West (Davis et al., 2005; Zwally et al., 2005; Shepherd and Wingham, 2007; Pritchard et al., 2009; Flament and Remy, 2012; Schröder et al., 2018). The thinning signals are modest $\left(\sim 50 \mathrm{~cm} \mathrm{yr}^{-1}\right)$ in comparison to observations in the Amundsen Sea sector, but we note that these observations were made, in some cases, decades after the loss of the Cook West Ice Shelf. Thinning rates could have been higher in the immediate years following ice shelf retreat, as observed in the Crane Glacier, which formerly flowed into the Larsen B Ice Shelf (e.g. Rott et al., 2018). However, from 2010 onwards, inland thinning upstream of Cook West appears to have slowed down or ceased (McMillan et al., 2014), suggesting that the system might be approaching equilibrium following the loss of the Cook West Ice Shelf.

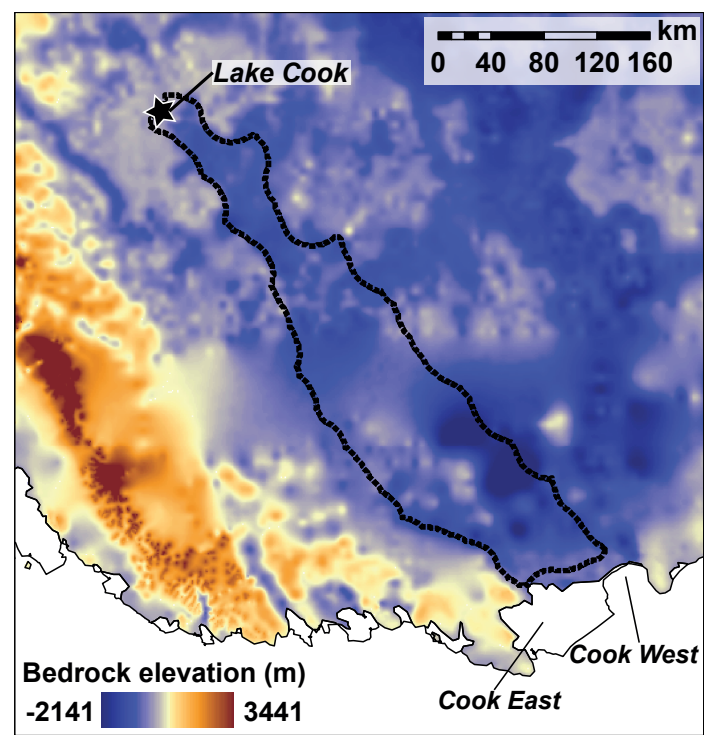

Figure 7. Region of most probable flow path (dashed line) of subglacial Lake Cook (Flament et al., 2014) overlain on bed elevation from Bedmap2 (Fretwell et al., 2013).

\subsubsection{Behaviour of Cook West post ice shelf loss}

Since the near-complete loss of the Cook West Ice Shelf, the ice front has fluctuated by $\sim 3 \mathrm{~km}$, but there have been no signs of a substantial re-advance (Figs. 5 and 6). As a consequence of the increase in Cook West's velocity following the retreat of its ice shelf, its strain rate near the ice front will have increased (Benn et al., 2007). This may explain the absence of a re-advance because the increase in strain rate has resulted in an increase in the calving rate. However, the fact that the ice front position fluctuates by $\sim 3 \mathrm{~km}$ suggests that other external factors may also be important in stabilizing the ice front position.

The retreat of the Cook West Ice Shelf resulted in the formation of an embayment, which has been growing in size as the neighbouring Cook East Ice Shelf advanced (Fig. 1). This embayment is typically filled with landfast sea ice, which may act to stabilize ice tongues (Massom et al., 2010). Conversely, sea ice break-out events have been linked to major instability and calving events elsewhere in East Antarctica (Miles et al., 2017). Whilst we observe calving events with sea ice present, leading to the build-up of ice mélange at the ice front, the continuous presence of landfsat sea ice and mélange appears to be important in enabling ice front advance (Fig. 8). Between 2009 and 2013 the Cook West ice front maintained approximately the same position (Fig. 8a), suggesting that repeated calving events prevented ice front advance. Using the MODIS Worldview viewer, we observe multiple sea ice break-out events during this time period. In contrast, between 2014 and 2016 the ice front advanced $\sim 3 \mathrm{~km}$, during which we observe no break-out events and see that landfast sea ice and mélange were continuously 


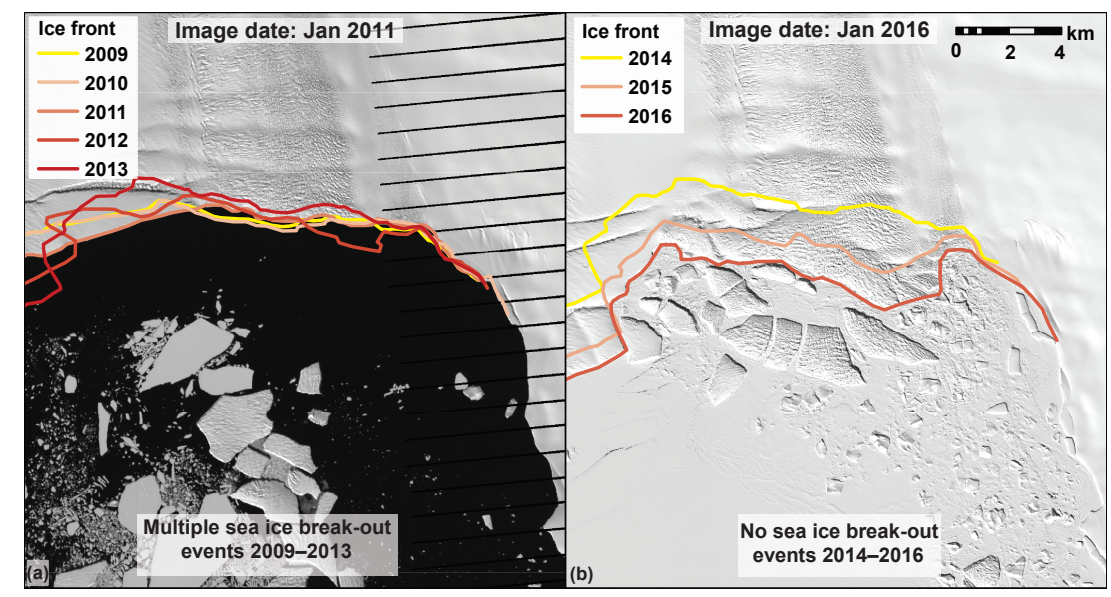

Figure 8. Relationship between ice front position of Cook West and the presence of landfast sea ice and mélange at its ice front. (a) Mapped ice front position overlain on a Landsat-7 image between 2009 and 2013, during which multiple sea ice break-out events were observed and there is little change in ice front position. (b) Mapped ice front position overlain on a Landsat-8 image between 2014 and 2016 , during which no sea ice break-out events were observed and the ice front was able to advance. Note the build-up of ice mélange near the ice front.

present at the ice front (Fig. 8b). This suggests that the back pressure applied by the landfast sea ice and mélange was enough to limit calving and enable ice front advance. This behaviour is similar to seasonal ice front fluctuations of some outlet glaciers in Greenland, where the seasonal formation of mélange inhibits calving, resulting in ice front advance (e.g. Amundsen et al., 2010; Todd and Christoffersen, 2014). The annual resolution of our data makes it difficult to determine if these fluctuations in ice front position have a direct effect on the velocity of Cook West because calving events occur on a subannual scale. Future investigation into this process is important because the interaction between ice front position, landfast sea ice, mélange, and ice dynamics following the loss of ice shelves is poorly understood in Antarctica and might be an important process missing in current numerical models (e.g. Massom et al., 2018) simulating future sea level contributions from the ice sheet (e.g. Golledge et al., 2015; DeConto and Pollard, 2016). The recent behaviour of Cook West could be one of the clearest modern-day observations for this process.

\subsection{What caused the calving behaviour of the Cook ice shelves?}

Despite their close proximity, the behaviour of the Cook East and Cook West ice shelves differs over the observational period. This can potentially be explained by the contrasting structures of the ice shelves. Inspection of the Cook East Ice Shelf (Fig. 2) shows little evidence of crevassing or fracturing throughout the observational period, whereas the Cook West Ice Shelf (Fig. 5b, c, d) was heavily crevassed and comparatively structurally weaker. This resulted in a different type of calving behaviour, whereby Cook East underwent infrequent tabular calving events, whilst Cook West underwent more frequent disintegration-type calving events (e.g. Liu et al., 2015). The contrasting calving style is unlikely to have been driven by environmental forcing, as inferred by Liu et al. (2015) for some other Antarctic ice shelves, because the proximity of both ice shelves means they are likely to receive similar forcing. Instead, it is more likely that the underlying bed topography where the ice shelves approach floatation is more important (e.g. Bassis and Ma, 2015). However, even taking into consideration the structurally weak nature of the Cook West Ice Shelf, there still must have been significant ocean climate forcing in order to force the complete loss of its floating ice shelf.

The widespread retreat of outlet glaciers in the Antarctic Peninsula (Cook et al., 2016) and the collapse of the Larsen B Ice Shelf (e.g. Scambos et al., 2003) have been linked to an increase in surface air temperatures and warm ocean forcing, while the rapid thinning of ice shelves in the Amundsen Sea sector and at Totten Glacier have been linked to intrusions of modified Circumpolar Deep Water (mCDW) (e.g. Jenkins et al., 2010; Rintoul et al., 2016). Satellite and modelled estimates of the present-day basal melt rate of the remaining Cook East Ice Shelf are low, suggesting that, on average, it receives a relatively weak ocean heat source (Depoorter et al., 2013; Rignot et al., 2013; Kusahara et al., 2017). Given the proximity of Cook East to Cook West, it is also likely that Cook West also receives a relatively weak oceanic heat source. We also do not observe any surface melt features in the form of supraglacial lakes or channels during our observations, and regional ice core records show no long-term trend in accumulation (Goursaud et al., 2017). Thus, these are not the ocean climate conditions which would typically be associated with the retreat, thinning, or catastrophic loss of ice shelves. Therefore, it is likely that the rapid and nearcomplete loss of the Cook West Ice Shelf was driven by 


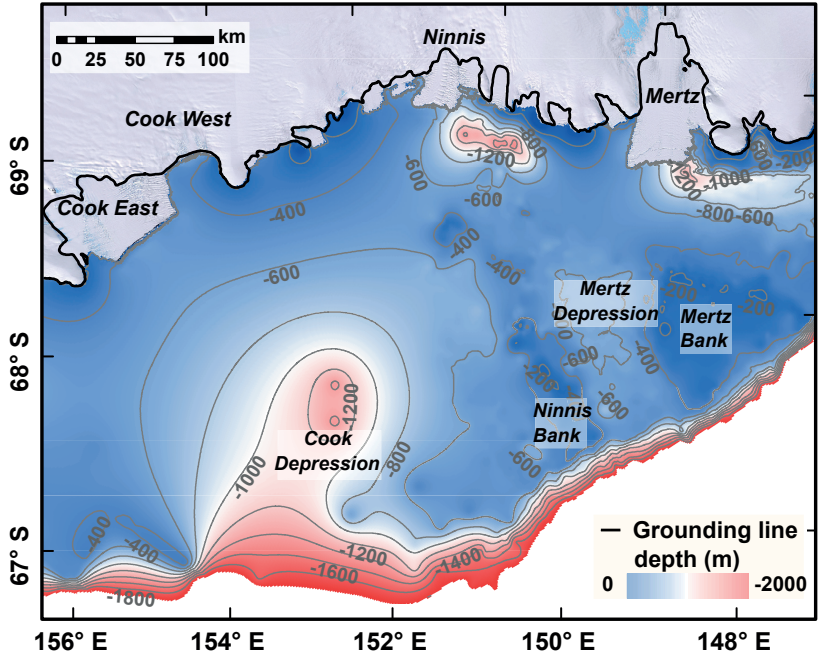

Figure 9. General Bathymetric Chart of the Oceans (GEBCO) bathymetry of the Cook-Ninnis-Mertz region overlain on the Landsat Image Mosaic of Antarctica (LIMA). Note location of the Cook Depression on the continental shelf.

ocean climate conditions that were likely quite different from the present day.

Multiple studies point towards a shift in climate towards greater decadal extremes since the mid-20th century in the wider Cook-Ninnis-Mertz region (Fig. 9). Reconstructions of sea surface conditions over the past 250 year show that since 1960 there has been an increase in glacial meltwater as more intense winds enhance mCDW intrusions onto the continental shelf (Campagne et al., 2015). This deviates from the cyclic behaviour of sea surface conditions driven by the periodic formation of the Mertz polynya in association with the $\sim 70$-year calving cycle of the Mertz Glacier Tongue (Campagne et al., 2015; Giles, 2017). Reconstructions of ice discharge of the region from marine sediment cores west of Mertz show an increase in ice discharge since $\sim 1980$, the magnitude of which might be unprecedented throughout the Holocene (Crespin et al., 2014). This was linked to an out-ofphase calving event of Ninnis Glacier (Crespin et al., 2014), but we suggest the increase in discharge of Cook West following the loss of its ice shelf may have also contributed to this recorded increase in ice discharge.

In addition, a climate coupling exists between the CookNinnis-Mertz region and New Zealand's glaciers, whereby large-scale atmospheric waves connect the two regions (Crespin et al., 2014; Mackintosh et al., 2017). The onset of the rapid retreat of mountain glaciers in New Zealand occurred around the 1940s; this retreat continued at varying rates until the 1990s, when glaciers advanced in response to regional cooling (Mackintosh et al., 2017). A similar trend is seen in the Cook-Ninnis-Mertz region; along with Cook West (Fig. 5), Ninnis Glacier underwent a major retreat in the 1940s (Frezzotti et al., 1998), and there was a switch from dominant outlet glacier retreat across the wider region in the 1970s and 1980s to cooler conditions and glacier advance from 1990 to 2010 (Miles et al., 2013). A similar change in wind pattern may also be reflected in temperature reconstructions from 1870 to 2010 in the New Zealand subantarctic islands, which lie directly between the Cook-Ninnis-Mertz region and New Zealand, where there is an abrupt switch towards a more variable climate from the 1940s onwards (Turney et al., 2017). Evidence of such variability is also recorded in wind direction at the nearest research station, Dumont d'Urville, where there was an abrupt shift in the 1990s towards more easterly winds (Fig. 10). Taken together, analysis of these studies hints at warmer regional climate during periods of the mid-20th century and a cooler climate from the 1990s onwards. This is consistent with our interpretation that warmer-than-present ocean climate forcing is likely to have driven the rapid retreat of the Cook West Ice Shelf.

At present there have been no subsurface ocean measurements in the immediate vicinity of Cook West Glacier. However, the local oceanography west of Cook near the Mertz and Ninnis glaciers is one of the most extensively studied in Antarctica (Beaman et al., 2011; Kusahara et al., 2011; Williams et al., 2011; Tamura et al., 2012; Campagne et al., 2015; Aoki et al., 2017). Numerical modelling has suggested that a key component of the local oceanography in the Mertz-Ninnis region is the westward advection of warm mCDW from a depression on the continental shelf in front of Cook Glacier (Kusahara et al., 2017) (Fig. 9). The amount of warm $\mathrm{mCDW}$ advected onto the continental shelf from the bathymetric depression is sensitive to both interannual variability in atmospheric forcing and large changes in the regional "icescape" (e.g. calving of the Mertz Glacier Tongue) (Cougnon et al., 2017; Kusahara et al., 2017). Therefore, the more variable climate in the mid-20th century may have resulted in greater mCDW intrusions. There have been no observations of the bathymetry in front of Cook Glacier, so it is not known if there are any connecting troughs to this depression which could facilitate the delivery of warm mCDW intrusions towards the Cook outlet grounding line. However, given the proximity of a potential ocean heat source to the Cook West Glacier and the absence of any other obvious drivers, we suggest that periodic mCDW intrusions forced by a more variable climate could have been important in driving the rapid retreat of the Cook West Ice Shelf. It is possible that any climatically forced initial retreat of the Cook West Ice Shelf could have been enhanced if contact with a bathymetric pinning point was lost, but we do not see any evidence of icebergs grounding on any former pinning point since its retreat. However, we do note that the loss of the Cook West Ice Shelf must have occurred shortly after the calving of the neighbouring Cook East Ice Shelf between 1963 and 1973. Therefore, any loss of contact with the neighbouring Cook East Ice Shelf may have had a destabilizing effect on Cook West, increasing its vulnerability to retreat (e.g. Albrecht and Levermann, 2014). 


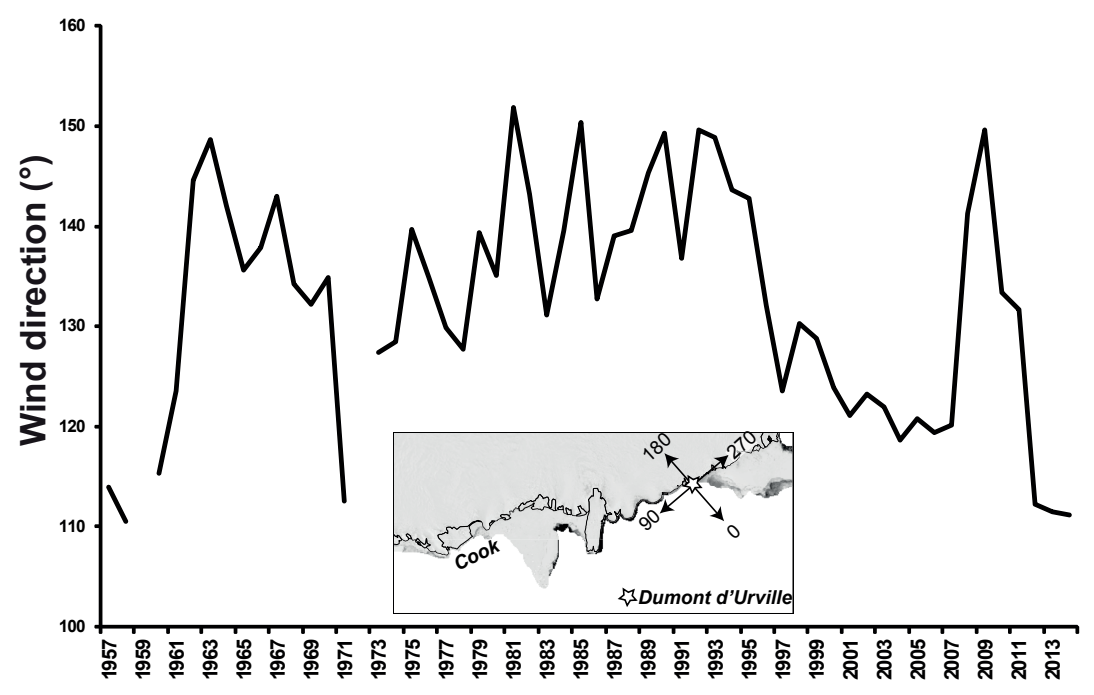

Figure 10. Mean annual wind direction from Dumont d'Urville research station during 1957-2014.

The tabular calving regime of the Cook East Ice Shelf means its observed behaviour is more challenging to interpret than the neighbouring Cook West. Cyclic tabular calving events are typically considered to be part of a natural cycle of advance and retreat linked to the internal stress regimes of ice shelves, e.g. from the Ross Ice Shelf (Joughin and MacAyeal, 2005) and Amery Ice Shelf (Fricker et al., 2002), and/or bathymetric constraints, e.g. at the Mertz Glacier Tongue (Giles, 2017). However, the potential impact of multi-decadal climate variability on the periodicity and magnitude of major calving events has only rarely been considered. Whilst it is difficult to interpret any changes in the calving cycle of Cook East Ice Shelf owing to the lack of calving observations, there are notable differences between its current cycle and its previous calving cycle. Its present-day ice front position is around $6 \mathrm{~km}$ further advanced than its estimated maximum in the previous calving cycle. Given that there are no obvious rifts and that these can take years to fully develop, it is likely that its next calving event will be from a significantly more advanced position than the last event between 1963 and 1973. Furthermore, the unusually deep retreat of the Cook East ice front into the dynamic section of the ice shelf in the 1970s (Fig. 2) possibly indicates that it calved earlier and deeper than it perhaps would have under a natural cycle of advance and retreat. Therefore, the behaviour of the Cook East Ice Shelf may also be consistent with a more variable climate in the mid-20th century (e.g. Crespin et al., 2014; Campagne et al., 2015; Turney et al., 2017) driving its deep retreat into its embayment, whilst the cooler conditions of the more recent decades are associated with the advance and stability of the ice shelf. Future investigation is needed into the potential influence of climate variability on the long-term calving cycles of medium to large ice shelves in Antarctica.

\section{Conclusion}

We have shown that, despite little change over the most recent decade, there have been dynamic changes in the velocity of both the Cook East and West glaciers during periods over the past $\sim 45$ years. For Cook East we provide one of the few observations linking a short-lived increase in velocity to a subglacial flood event, in addition to a longer-term velocity increase of approximately $20 \%$ between 1989 and 2001. For Cook West we link a doubling of its velocity to the near-complete loss of its floating ice shelf between 1973 and 1989, which may have been forced by a more variable climate in the mid-20th century. Since the loss of the Cook West Ice Shelf, there have been no signs of a comparable readvance, but small cycles in ice front position appear to be linked to sea ice conditions.

The changes we observe highlight the importance of extending observational records of glacier change in Antarctica, which are typically confined to satellite altimetry and velocity measurements from the mid-1990s onwards. It is possible that in regions where there is multi-decadal climate variability this may not be a long enough time period to assess the sensitivity of outlet glaciers to changes in climate. In the case of Cook West, the changes in velocity we observe in response to the loss of its floating ice shelf are some of the largest recorded in the satellite era in Antarctica. However, in terms of observations of subsurface ocean temperatures, bathymetry, and bed topography, it is one of the least studied. This needs to be addressed in order to fully understand the processes driving changes in the recent past and improve our understanding of how it will respond to future changes in climate. This is important because Cook Glacier drains a large proportion of the Wilkes Subglacial Basin and may have the potential to make future rapid sea level contributions. 
Data availability. Landsat and ARGON imagery along with the aerial photography used in this study is freely available from Earth Explorer. Cosi-Corr is an ENVI plug-in and can be freely downloaded via its we bpage. GEBCO bathymetric data are available to download from https://www. gebco.net/ (https://doi.org/10.1002/2015EA000107, https://doi.org/ 10.1175/1520-0442(2004)017<2890:TSRPTA>2.0.CO;2). Meteorological data from Dumont d'Urville are available from the SCAR MET READER. Ice front position shapefiles and velocity grids are available from the corresponding author.

Supplement. The supplement related to this article is available online at: https://doi.org/10.5194/tc-12-3123-2018-supplement.

Author contributions. BM conceived the study, designed and executed the method presented in the research, conducted the analysis, and drafted the original manuscript. All authors discussed the results and contributed towards editing the manuscript.

Competing interests. The authors declare that they have no conflict of interest.

Acknowledgements. This work was partly funded by the Natural Environment Research Council (grant number: NE/R000824/1) and partly by a Durham University Doctoral Scholarship. Landsat imagery was provided free of charge by the US Geological Survey Earth Resources Observation and Science Center. We thank the DigitalGlobe Foundation for the provision of WorldView imagery free of charge. We thank Ed L. Pope for proving subglacial lake drainage basins and Thomas Flament for providing subglacial flow path data. We thank Poul Chirstoffersen and Jeremy M. Lloyd for valuable discussions. We would like to thank Ted Scambos and an anonymous reviewer for reviewing the manuscript, along with the editor, Etienne Berthier, for providing constructive comments which led to the improvement of this paper.

Edited by: Etienne Berthier

Reviewed by: Ted Scambos and one anonymous referee

\section{References}

Albrecht, T. and Levermann, A.: Spontaneous ice-front retreat caused by disintegration of adjacent ice shelf in Antarctica, Earth Planet. Sc. Lett., 393, 26-30, 2014.

Amundson, J. M., Fahnestock, M., Truffer, M., Brown, J., Luthi, M. P., and Motyka, R. J.: Ice mélange dynamics and implications for terminus stability, Jakobshavn Isbrae Greenland, J. Geophys. Res., 115, F01005, https://doi.org/10.1029/2009JF001405, 2010. Aoki, S., Kobayashi, R., Rintoul, S. R., Tamura, T., and Kusahara, $\mathrm{K}$.: Changes in water properties and flow regime on the continental shelf off the Adelie/George V Land coast, East Antarctica, after glacier tongue calving, J. Geophys. Res.-Oceans, 122, 6277-6294, 2017.
Bassis, J. N. and Ma, Y.: Evolution of basal crevasses links ice shelf stability to ocean forcing, Earth Planet. Sc. Lett., 409, 203-211, 2015.

Beaman, R. J., O’Brien, P. E., Post, A. L., and De Santis, L.: A new high-resolution bathymetry model for the Terre Adelie and George V continental margin, East Antarctica, Antarct. Sci., 23, 95-103, 2011.

Benn, D. I., Warren, C. R., and Mottram, R. H.: Calving processes and the dynamics of calving glaciers, Earth-Sci. Rev., 82, 143179, 2007.

Bertram, R. A., Wilson, D. J., van de Flierdt, T., McKay, R. M., Patterson, M. O., Jimenez-Espejo, F. J., Escutia, C., Duke, G. C., Taylor-Silva, B. I., and Riesselman, C. R.: Pliocene deglacial event timelines and the biogeochemical response offshore Wilkes Subglacial Basin, East Antarctica, Earth Planet. Sc. Lett., 494, 109-116, 2018.

Campagne, P., Crosta, X., Houssais, M. N., Swingedouw, D., Schmidt, S., Martin, A., Devred, E., Capo, S., Marieu, V., Closset, I., and Masse, G.: Glacial ice and atmospheric forcing on the Mertz Glacier Polynya over the past 250 years, Nat. Commun., 6, 6642, https://doi.org/10.1038/ncomms7642, 2015.

Cook, A. J., Holland, P. R., Meredith, M. P., Murray, T., Luckman, A., and Vaughan, D. G.: Ocean forcing of glacier retreat in the western Antarctic Peninsula, Science, 353, 283-286, 2016.

Cook, C. P., van de Flierdt, T., Williams, T., Hemming, S. R., Iwai, M., Kobayashi, M., Jimenez-Espejo, F. J., Escutia, C., Gonzalez, J. J., Khim, B. K., McKay, R. M., Passchier, S., Bohaty, S. M., Riesselman, C. R., Tauxe, L., Sugisaki, S., Galindo, A. L., Patterson, M. O., Sangiorgi, F., Pierce, E. L., Brinkhuis, H., and Scientists, I. E.: Dynamic behaviour of the East Antarctic ice sheet during Pliocene warmth, Nat. Geosci., 6, 765-769, 2013.

Cougnon, E. A., Galton-Fenzi, B. K., Rintoul, S. R., Legrésy, B., Williams, G. D., Fraser, A. D., and Hunter, J. R.: Regional Changes in Icescape Impact Shelf Circulation and Basal Melting, Geophys. Res. Lett., 44, 11519-511527, 2017.

Crespin, J., Yam, R., Crosta, X., Masse, G., Schmidt, S., Campagne, P., and Shemesh, A.: Holocene glacial discharge fluctuations and recent instability in East Antarctica, Earth Planet. Sc. Lett, 394, 38-47, 2014.

Davis, C. H., Li, Y. H., McConnell, J. R., Frey, M. M., and Hanna, E.: Snowfall-driven growth in East Antarctic ice sheet mitigates recent sea-level rise, Science, 308, 1898-1901, 2005.

DeConto, R. M. and Pollard, D.: Contribution of Antarctica to past and future sea-level rise, Nature, 531, 591-597, 2016.

Depoorter, M. A., Bamber, J. L., Griggs, J. A., Lenaerts, J. T. M., Ligtenberg, S. R. M., van den Broeke, M. R., and Moholdt, G.: Calving fluxes and basal melt rates of Antarctic ice shelves, Nature, 502, 89-92, 2013.

Flament, T. and Remy, F.: Dynamic thinning of Antarctic glaciers from along-track repeat radar altimetry, J. Glaciol., 58, 830-840, 2012.

Flament, T., Berthier, E., and Rémy, F.: Cascading water underneath Wilkes Land, East Antarctic ice sheet, observed using altimetry and digital elevation models, The Cryosphere, 8, 673-687, https://doi.org/10.5194/tc-8-673-2014, 2014.

Fretwell, P., Pritchard, H. D., Vaughan, D. G., Bamber, J. L., Barrand, N. E., Bell, R., Bianchi, C., Bingham, R. G., Blankenship, D. D., Casassa, G., Catania, G., Callens, D., Conway, H., Cook, A. J., Corr, H. F. J., Damaske, D., Damm, V., Ferracci- 
oli, F., Forsberg, R., Fujita, S., Gim, Y., Gogineni, P., Griggs, J. A., Hindmarsh, R. C. A., Holmlund, P., Holt, J. W., Jacobel, R. W., Jenkins, A., Jokat, W., Jordan, T., King, E. C., Kohler, J., Krabill, W., Riger-Kusk, M., Langley, K. A., Leitchenkov, G., Leuschen, C., Luyendyk, B. P., Matsuoka, K., Mouginot, J., Nitsche, F. O., Nogi, Y., Nost, O. A., Popov, S. V., Rignot, E., Rippin, D. M., Rivera, A., Roberts, J., Ross, N., Siegert, M. J., Smith, A. M., Steinhage, D., Studinger, M., Sun, B., Tinto, B. K., Welch, B. C., Wilson, D., Young, D. A., Xiangbin, C., and Zirizzotti, A.: Bedmap2: improved ice bed, surface and thickness datasets for Antarctica, The Cryosphere, 7, 375-393, https://doi.org/10.5194/tc-7-375-2013, 2013.

Frezzotti, M., Cimbelli, A., and Ferrigno, J. G.: Ice-front change and iceberg behaviour along Oates and George V Coasts, Antarctica, 1912-96, Ann. Glaciol., 27, 643-650, 1998.

Fricker, H. A., Young, N. W., Allison, I., and Coleman, R.: Iceberg calving from the Amery Ice Shelf, East Antarctica, Ann. Glaciol., 34, 241-246, 2002.

Furst, J. J., Durand, G., Gillet-Chaulet, F., Tavard, L., Rankl, M., Braun, M., and Gagliardini, O.: The safety band of Antarctic ice shelves, Nat. Clim. Change, 6, 479-482, 2016.

Giles, A. B.: The Mertz Glacier Tongue, East Antarctica. Changes in the past 100 years and its cyclic nature - Past, present and future, Remote Sens. Environ., 191, 30-37, 2017.

Golledge, N. R., Kowalewski, D. E., Naish, T. R., Levy, R. H., Fogwill, C. J., and Gasson, E. G. W.: The multi-millennial Antarctic commitment to future sea-level rise, Nature, 526, 421-425, 2015.

Goursaud, S., Masson-Delmotte, V., Favier, V., Preunkert, S., Fily, M., Gallée, H., Jourdain, B., Legrand, M., Magand, O., Minster, B., and Werner, M.: A 60-year ice-core record of regional climate from Adélie Land, coastal Antarctica, The Cryosphere, 11, 343362, https://doi.org/10.5194/tc-11-343-2017, 2017.

Heid, T. and Kääb, A.: Evaluation of existing image matching methods for deriving glacier surface displacements globally from optical satellite imagery, Remote Sens. Environ., 118, 339-355, 2012.

Hughes, T. J.: The Weak Underbelly of the West Antarctic IceSheet, J. Glaciol., 27, 518-525, 1981.

Jansen, D., Luckman, A. J., Cook, A., Bevan, S., Kulessa, B., Hubbard, B., and Holland, P. R.: Brief Communication: Newly developing rift in Larsen C Ice Shelf presents significant risk to stability, The Cryosphere, 9, 1223-1227, https://doi.org/10.5194/tc-91223-2015, 2015.

Jenkins, A., Dutrieux, P., Jacobs, S. S., McPhail, S. D., Perrett, J. R., Webb, A. T., and White, D.: Observations beneath Pine Island Glacier in West Antarctica and implications for its retreat, Nat. Geosci., 3, 468-472, 2010.

Joughin, I. and MacAyeal, D. R.: Calving of large tabular icebergs from ice shelf rift systems, Geophys. Res. Lett., 32, L02501, https://doi.org/10.1029/2004GL020978, 2005.

Joughin, I., Smith, B. E., and Medley, B.: Marine Ice Sheet Collapse Potentially Under Way for the Thwaites Glacier Basin, West Antarctica, Science, 344, 735-738, 2014.

Konrad, H., Shepherd, A., Gilbert, L., Hogg, A. E., McMillan, M., Muir, A., and Slater, T.: Net retreat of Antarctic glacier grounding lines, Nat. Geosci., 11, 258-262, 2018.

Kusahara, K., Hasumi, H., and Williams, G. D.: Impact of the Mertz Glacier Tongue calving on dense water formation and export,
Nat. Commun., 2, 159, https://doi.org/10.1038/ncomms1156, 2011.

Kusahara, K., Hasumi, H., Fraser, A. D., Aoki, S., Shimada, K., Williams, G. D., Massom, R., and Tamura, T.: Modeling OceanCryosphere Interactions off Adélie and George V Land, East Antarctica, J. Climate, 30, 163-188, 2017.

Leprince, S., Ayoub, F., Klinger, Y., and Avouac, J. P.: CoRegistration of Optically Sensed Images and Correlation (COSICorr): an operational methodology for ground deformation measurements, in: 2007 Ieee International Geoscience and Remote Sensing Symposium, Barcelona, Spain, 23-28 July 2007, IEEE, 1943-1946, https://doi.org/10.1109/Igarss.2007.4423207, 2007.

Liu, Y., Moore, J. C., Cheng, X., Gladstone, R. M., Bassis, J. N., Liu, H., Wen, J., and Hui, F.: Ocean-driven thinning enhances iceberg calving and retreat of Antarctic ice shelves, P. Natl. Acad. Sci. USA, 112, 3263-3268, 2015.

Lovell, A., Stokes, C., and Jamieson, S.: Sub-decadal variations in outlet glacier terminus positions in Victoria Land, Oates Land and George V Land, East Antarctica (1972-2013), Antarct. Sci., 29, 468-483, https://doi.org/10.1017/S0954102017000074, 2017.

Mackintosh, A. N., Anderson, B. M., Lorrey, A. M., Renwick, J. A., Frei, P., and Dean, S. M.: Regional cooling caused recent New Zealand glacier advances in a period of global warming, Nat. Commun., 8, 14202, https://doi.org/10.1038/ncomms14202, 2017.

Massom, R. A., Giles, A. B., Fricker, H. A., Warner, R. C., Legresy, B., Hyland, G., Young, N., and Fraser, A. D.: Examining the interaction between multi-year landfast sea ice and the Mertz Glacier Tongue, East Antarctica: Another factor in ice sheet stability?, J. Geophys. Res., 115, C12027, https://doi.org/10.1029/2009JC006083, 2010.

Massom, R. A., Scambos, T. A., Bennetts, L. G., Reid, P., Squire, V. A., and Stammerjohn, S. E.: Antarctic ice shelf disintegration triggered by sea ice loss and ocean swell, Nature, 558, 383-389, 2018.

McMillan, M., Corr, H., Shepherd, A., Ridout, A., Laxon, S., and Cullen, R.: Three-dimensional mapping by CryoSat-2 of subglacial lake volume changes, Geophys. Res. Lett., 40, 43214327, 2013.

McMillan, M., Shepherd, A., Sundal, A., Briggs, K., Muir, A., Ridout, A., Hogg, A., and Wingham, D.: Increased ice losses from Antarctica detected by CryoSat-2, Geophys. Res. Lett., 41, 3899-3905, 2014.

Mengel, M. and Levermann, A.: Ice plug prevents irreversible discharge from East Antarctica, Nat. Clim. Change, 4, 451-455, 2014.

Miles, B. W. J., Stokes, C. R., Vieli, A., and Cox, N. J.: Rapid, climate-driven changes in outlet glaciers on the Pacific coast of East Antarctica, Nature, 500, 563-566, 2013.

Miles, B. W. J., Stokes, C. R., and Jamieson, S. S. R.: Pan-ice-sheet glacier terminus change in East Antarctica reveals sensitivity of Wilkes Land to sea-ice changes, Science Advances, 2, e1501350, https://doi.org/10.1126/sciadv.1501350, 2016.

Miles, B. W. J., Stokes, C. R., and Jamieson, S. S. R.: Simultaneous disintegration of outlet glaciers in Porpoise Bay (Wilkes Land), East Antarctica, driven by sea ice break-up, The Cryosphere, 11, 427-442, https://doi.org/10.5194/tc-11-427-2017, 2017. 
Moon, T. and Joughin, I.: Changes in ice front position on Greenland's outlet glaciers from 1992 to 2007, J. Geophys. Res., 113, F02022, https://doi.org/10.1029/2007JF000927, 2008.

Mouginot, J., Rignot, E., and Scheuchl, B.: Sustained increase in ice discharge fromthe Amundsen Sea Embayment, West Antarctica, from 1973 to 2013, Geophys. Res. Lett., 41, 1576-1584, 2014.

Mouginot, J., Rignot, E., Scheuchl, B., and Millan, R.: Comprehensive Annual Ice Sheet Velocity Mapping Using Landsat-8, Sentinel-1, and RADARSAT-2 Data, Remote Sens-Basel, 9, 364, https://doi.org/10.3390/rs9040364, 2017.

Paolo, F. S., Fricker, H. A., and Padman, L.: Volume loss from Antarctic ice shelves is accelerating, Science, 348, 327-331, https://doi.org/10.1126/science.aaa0940, 2015.

Paolo, F. S., Padman, L., Fricker, H. A., Adusumilli, S., Howard, S., and Siegfried, M. R.: Response of Pacific-sector Antarctic ice shelves to the El Niño/Southern Oscillation, Nat. Geosci., 11, 121-126, 2018.

Pritchard, H. D., Arthern, R. J., Vaughan, D. G., and Edwards, L. A.: Extensive dynamic thinning on the margins of the Greenland and Antarctic ice sheets, Nature, 461, 971-975, 2009.

Pritchard, H. D., Ligtenberg, S. R. M., Fricker, H. A., Vaughan, D. G., van den Broeke, M. R., and Padman, L.: Antarctic ice-sheet loss driven by basal melting of ice shelves, Nature, 484, 502-505, 2012.

Rignot, E.: Changes in ice dynamics and mass balance of the Antarctic ice sheet, Philos. T. R. Soc. A, 364, 1637-1655, 2006.

Rignot, E., Mouginot, J., and Scheuchl, B.: Ice Flow of the Antarctic Ice Sheet, Science, 333, 1427-1430, 2011.

Rignot, E., Jacobs, S., Mouginot, J., and Scheuchl, B.: Ice-Shelf Melting Around Antarctica, Science, 341, 266-270, 2013.

Rintoul, S. R., Silvano, A., Pena-Molino, B., van Wijk, E., Rosenberg, M., Greenbaum, J. S., and Blankenship, D. D.: Ocean heat drives rapid basal melt of the Totten Ice Shelf, Science Advances, 2, e1601610 https://doi.org/10.1126/sciadv.1601610, 2016.

Ritz, C., Edwards, T. L., Durand, G., Payne, A. J., Peyaud, V., and Hindmarsh, R. C. A.: Potential sea-level rise from Antarctic icesheet instability constrained by observations, Nature, 528, 115$118,2015$.

Rott, H., Abdel Jaber, W., Wuite, J., Scheiblauer, S., Floricioiu, D., van Wessem, J. M., Nagler, T., Miranda, N., and van den Broeke, M. R.: Changing pattern of ice flow and mass balance for glaciers discharging into the Larsen A and B embayments, Antarctic Peninsula, 2011 to 2016, The Cryosphere, 12, 12731291, https://doi.org/10.5194/tc-12-1273-2018, 2018.

Scambos, T., Hulbe, C., and Fahnestock, M.: Climate-induced ice shelf disintegration in the Antarctic Peninsula, Antarct. Res. Ser., 79, 79-92, 2003.

Scambos, T. A., Berthier, E., and Shuman, C. A.: The triggering of subglacial lake drainage during rapid glacier drawdown: Crane Glacier, Antarctic Peninsula, Ann. Glaciol., 52, 74-82, 2011.

Scherler, D., Leprince, S., and Strecker, M. R.: Glacier-surface velocities in alpine terrain from optical satellite imagery - Accuracy improvement and quality assessment, Remote Sens. Environ., 112, 3806-3819, 2008.

Schoof, C.: Ice sheet grounding line dynamics: Steady states, stability, and hysteresis, J. Geophys. Res., 112, F03S28, https://doi.org/10.1029/2006JF000664, 2007.

Schröder, L., Horwath, M., Dietrich, R., and Helm, V.: Four decades of surface elevation change of the Antarctic Ice Sheet from multi-mission satellite altimetry, The Cryosphere Discuss., https://doi.org/10.5194/tc-2018-49, in review, 2018.

Shepherd, A. and Wingham, D.: Recent sea-level contributions of the Antarctic and Greenland ice sheets, Science, 315, 15291532, 2007.

Siegfried, M. R., Fricker, H. A., Carter, S. P., and Tulaczyk, S.: Episodic ice velocity fluctuations triggered by a subglacial flood in West Antarctica, Geophys. Res. Lett., 43, 2640-2648, 2016.

Smith, B., Fricker, H., Joughin, I., and Tulaczyk, S.: An inventory of active subglacial lakes in Antarctica detected by ICESat (2003-2008), J. Glaciol., 55, 573-595, https://doi.org/10.3189/002214309789470879, 2009.

Stearns, L. A., Smith, B. E., and Hamilton, G. S.: Increased flow speed on a large East Antarctic outlet glacier caused by subglacial floods, Nat. Geosci., 1, 827-831, 2008.

Tamura, T., Williams, G. D., Fraser, A. D., and Ohshima, K. I.: Potential regime shift in decreased sea ice production after the Mertz Glacier calving, Nat. Commun., 3, 826, https://doi.org/10.1038/ncomms1820, 2012.

Todd, J. and Christoffersen, P.: Are seasonal calving dynamics forced by buttressing from ice mélange or undercutting by melting? Outcomes from full-Stokes simulations of Store Glacier, West Greenland, The Cryosphere, 8, 2353-2365, https://doi.org/10.5194/tc-8-2353-2014, 2014.

Turner, J., Colwell, S. R., Marshall, G. J., Lachlan-Cope, T. A., Carleton, A. M., Jones, P. D., Lagun, V., Reid, P. A., and Iagovkina, S.: The SCAR READER Project: Toward a HighQuality Database of Mean Antarctic Meteorological Observations, J. Climate, 17, 2890-2898, https://doi.org/10.1175/15200442(2004)017<2890:TSRPTA>2.0.CO;2, 2004.

Turney, C. S. M., Fogwill, C. J., Palmer, J. G., van Sebille, E., Thomas, Z., McGlone, M., Richardson, S., Wilmshurst, J. M., Fenwick, P., Zunz, V., Goosse, H., Wilson, K.-J., Carter, L., Lipson, M., Jones, R. T., Harsch, M., Clark, G., Marzinelli, E., Rogers, T., Rainsley, E., Ciasto, L., Waterman, S., Thomas, E. R., and Visbeck, M.: Tropical forcing of increased Southern Ocean climate variability revealed by a 140 -year subantarctic temperature reconstruction, Clim. Past, 13, 231-248, https://doi.org/10.5194/cp-13-231-2017, 2017.

Vaughan, D. G., Comiso, J. C., Allison, I., Carrasco, J., Kaser, G., Kwok, R., Mote, P., Murray, T., Paul, F., Ren, J., Rignot, E., Solomina, O., Steffen, K., and Zhang, T.: Observations: Cryosphere, in: Climate Change 2013: The Physical Science Basis. Contribution of Working Group I to the Fifth Assessment Report of the Intergovernmental Panel on Climate Change, edited by: Stocker, T. F., Qin, D., Plattner, G.-K., Tignor, M., Allen, S. K., Boschung, J., Nauels, A., Xia, Y., Bex, V., and Midgley, P. M., Cambridge University Press, Cambridge, United Kingdom and New York, NY, US, 2013.

Weatherall, P., Marks, K. M., Jakobsson, M., Schmitt, T., Tani, S., Arndt, J. E., Rovere, M., Chayes, D., Ferrini, V., and Wigley, R.: A new digital bathymetric model of the world's oceans, Earth Space Sci., 2, 331-345, https://doi.org/10.1002/2015EA000107, 2015.

Williams, G. D., Meijers, A. J. S., Poole, A., Mathiot, P., Tamura, T., and Klocker, A.: Late winter oceanography off the Sabrina and BANZARE coast $\left(117-128^{\circ} \mathrm{E}\right)$, East Antarctica, Deep-Sea Res. Pt. II, 58, 1194-1210, 2011. 
Williams, T., van de Flierdt, T., Hemming, S. R., Chung, E., Roy, M., and Goldstein, S. L.: Evidence for iceberg armadas from East Antarctica in the Southern Ocean during the late Miocene and early Pliocene, Earth Planet. Sc. Lett., 290, 351-361, 2010.

Willis, I. C., Pope, E. L., Leysinger Vieli, G. J. M. C., Arnold, N. S., and Long, S.: Drainage networks, lakes and water fluxes beneath the Antarctic ice sheet, Ann. Glaciol., 57, 96-108, 2016.
Wright, A. P., Siegert, M. J., Le Brocq, A. M., and Gore, D. B.: High sensitivity of subglacial hydrological pathways in Antarctica to small ice-sheet changes, Geophys. Res. Lett., 35, L17504, https://doi.org/10.1029/2008GL034937, 2008.

Zwally, H. J., Giovinetto, M. B., Li, J., Cornejo, H. G., Beckley, M. A., Brenner, A. C., Saba, J. L., and Yi, D. H.: Mass changes of the Greenland and Antarctic ice sheets and shelves and contributions to sea-level rise: 1992-2002, J. Glaciol., 51, 509-527, 2005. 